報文

\title{
污泥処理のシステム評価に関する研究
}

Study on Estimation of Sewage Sludge Treatment Systems (III)

松永一成, , 内田信一郎 ${ }^{* *}$, 油谷昭夫 ${ }^{* * *}$, 楠本光秀 $* * * *$, 橋本 隆 ${ }^{* * * * *}$

\section{2 污泥の有機物含有率}

消化プロセスにおける消化率は，式( 1 )に示すよう に，有機物含有率が増加すれば大きくなる関係がある が，乙れ迄のモデルでは污泥の有機物含有率を70\%の 一定値としてきた。本節では水処理で発生する污泥の 有機物含有率を変化させ污泥濃度を一定とし, 前述の 3 種の評価因子の変動状況を求めた．建設費について は図-13に，処理原価については図-14に，総エネルギ 一消費量については図-15に示した.

建設費は有機物含有率の増大に伴い消化方式では安 くなるが生方式では不変である。乙れは有機物含有率 が増大すると消化プロセスへ投入される有機物絶対量
が多くかつ, その分解率も大きくなるため, 後続の脱 水や焼却プロセスで処理の対象となる污泥量が小さく なり，乙れらに係る設備投資費が安くなるためである. 生方式では有機物含有率の増大は污泥濃度に影響しな いとしたため建設費は一定となった．消化方式と生方 式を比較すると, 建設費は消化方式では有機物含有率の 増大に伴い安くなり, 生方式の建設費に近づいていく.

消化方式では遠心濃縮のシステム(口)は, 重力濃縮 だけのシステム(イ)より常に建設費は安くなり, 生方 式においては, 逆に遠心濃縮のシステム(二)は, 重力濃 縮だけのシステム(ハ)より常に高くなっている。また システム(イ)と（ロ)及び(ハ)と(二)間のそれぞれの建

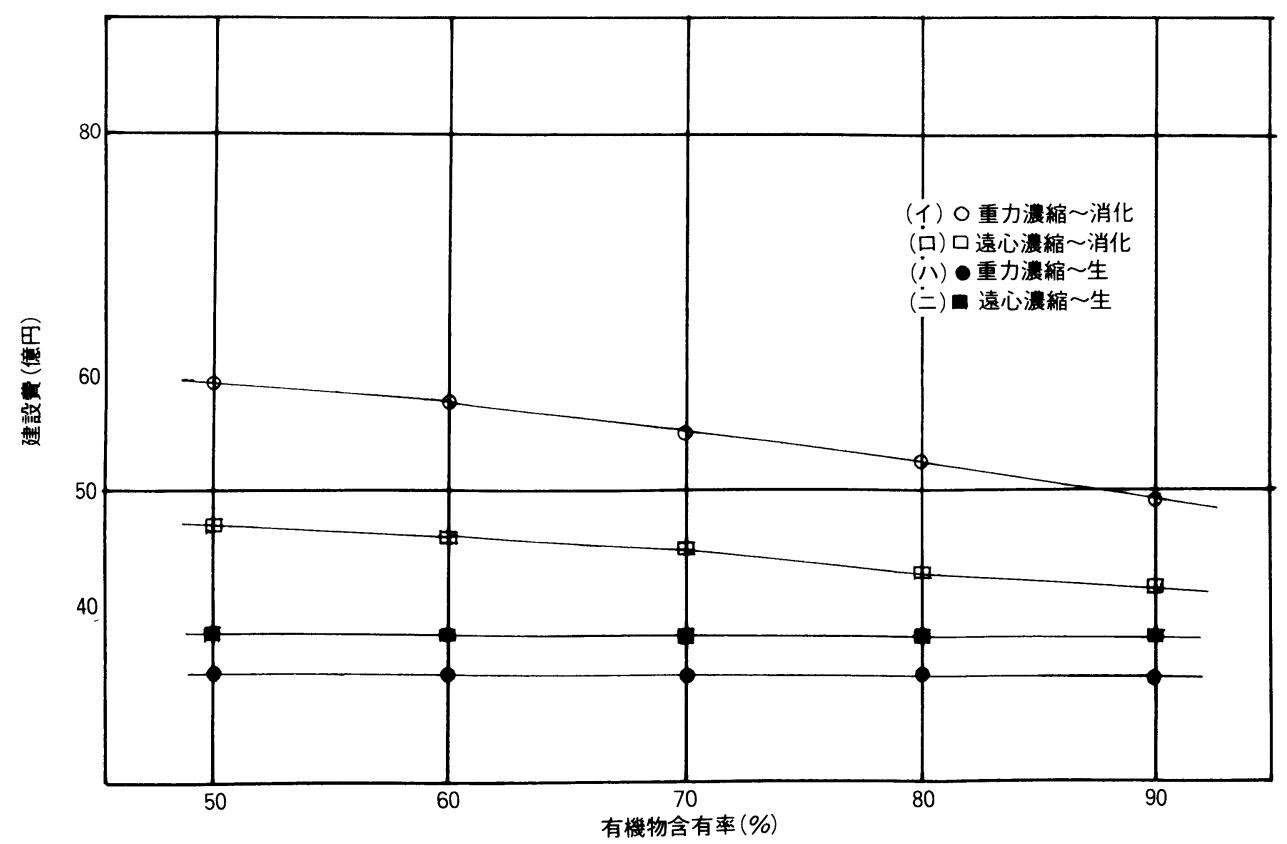

図-13 有機物含有率と建設費

\footnotetext{
* 大阪市下水道局局長 Kazunari MATSUNAGA

** 全 建設部計画課長代理 Shinichiro UCHIDA

*** 全 建設部機械課第 2 機械係長 Akio YUTANI

**** 全 建設部機械課第 2 機械係 Mitsuhide KUSUMOTO

*****（財）大阪市下水道技術協会 技術第 1 課長代理 Takashi HASHIMOTO
} 


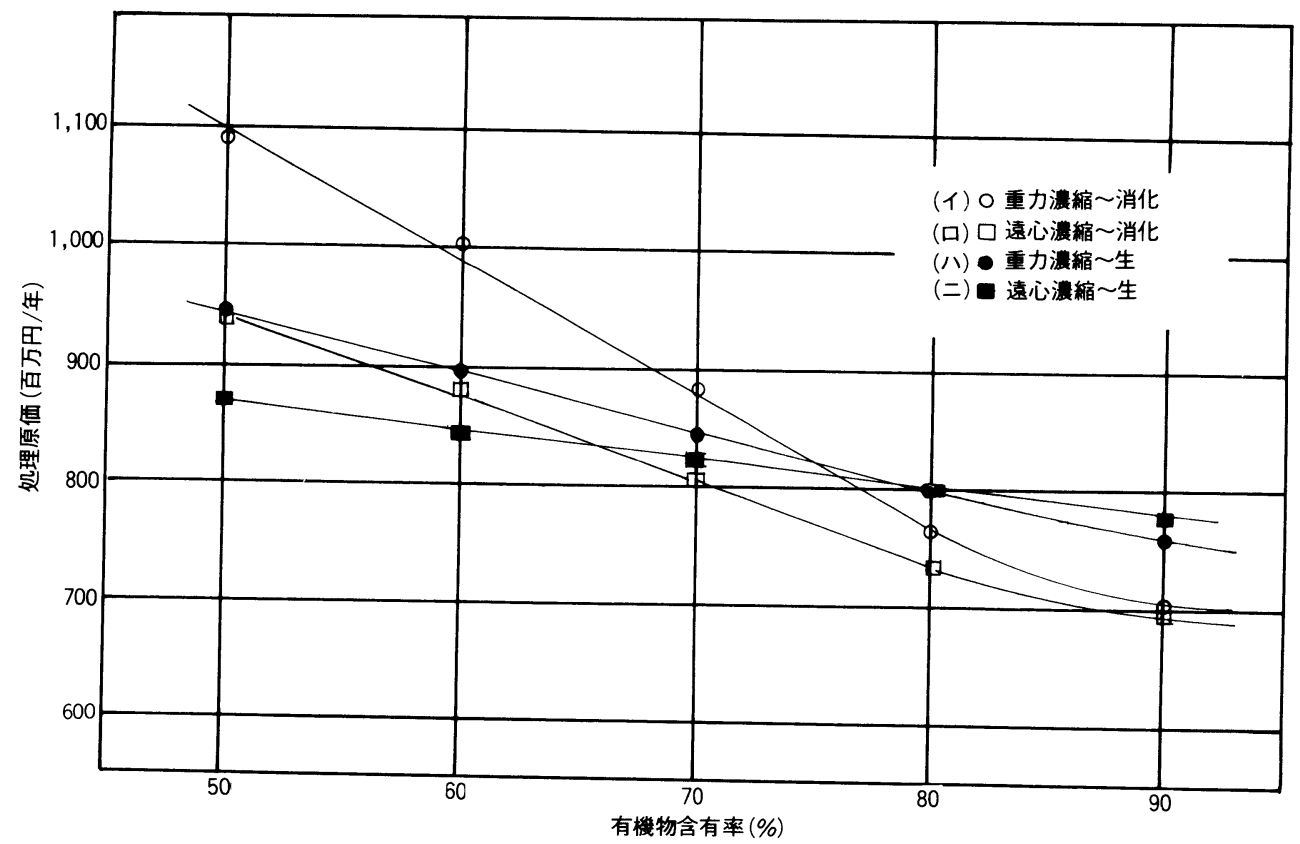

図-14 有機物含有率と処理原価

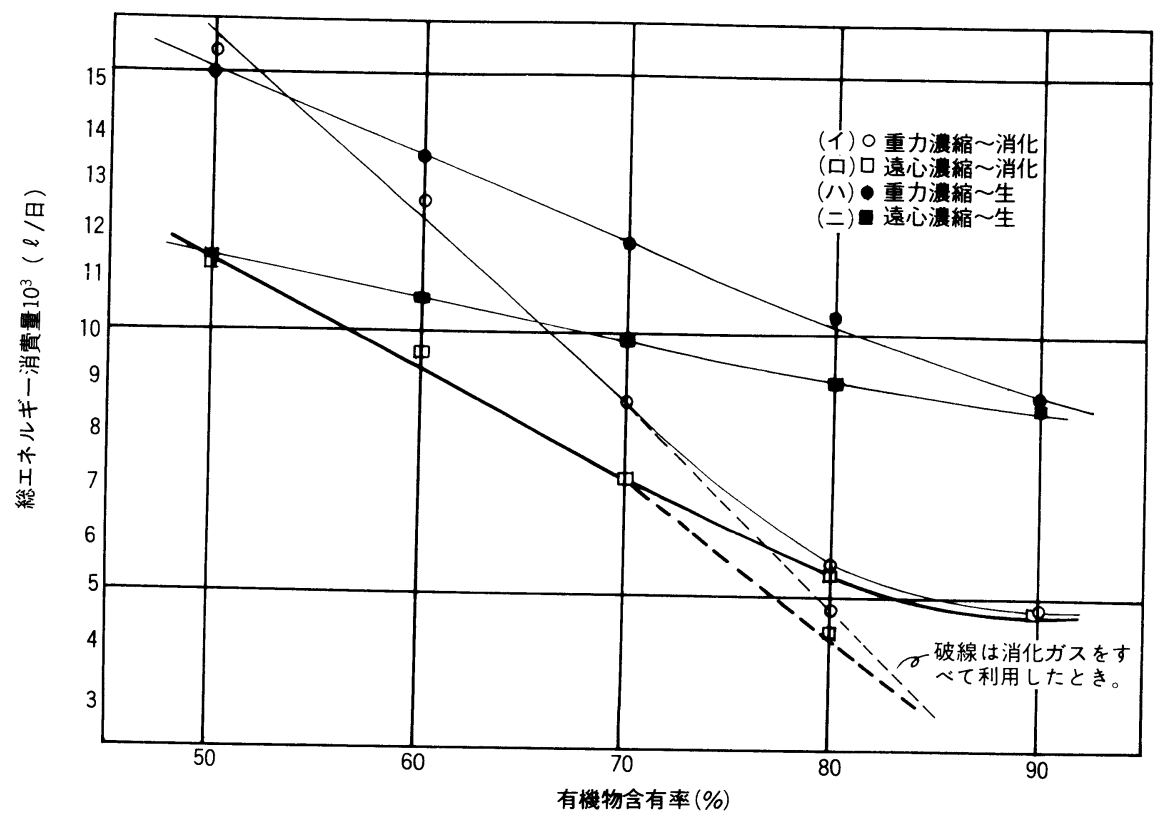

図-15 有機物含有率と総エネルギー消費量

設費の差は有機物含有率に関係なくほぼ一定となって いる.

処理原価は有機物含有率の増大に伴って各システム とも安くなる傾向を示しているが, 消化方式の(イ) (口)は, 生方式の(八)(二)に比べ有機物含有率の変化 の影響を大きく受けている.乙れは消化方式では, 脱 水用の薬品量, 及び余剰消化ガス発生量とケーキ発熱
量に関係する系外から購入する燃料が有機物含有率に 大きく影響されるが, 生方式ではケーキ発熱量に関係 する燃料のみが影響を受けるに過ぎないためである. 遠心濃縮の導入は, 有機物含有率の大半の領域で, 重力濃縮に比べ好理原価を抑制する効果がある。しか し有機物含有率の大きい領域では, その効果が小さく なる.乙れは, 污泥の有機物含有率が大きくなると消 
化方式に打いては遠心濃縮の導入により，余剩消化ガ スが焼却炬の燃料として必要となる量以上に発生し有 効利用されないまま大気へ放出されると仮定している ためであり，又生方式においては，エネルギー関連経 費の減少に伴って処理原価の低下がみられ，減価償却 や起債利子等の経費が処理原価に占める割合が大きく なっていくためである.

総エネルギー消費量についてみると各システムとも 有機物含有率の増大にともなって，減少する傾向を示 す，その消費量は消化システム(イ)(口)が生システム (ハ)(二)より一般的に少なくてすみ, 有機物含有率の 增大に伴ってての差は大きくなる，ての原因は前述の 処理原価之同様で, 脱水用の薬品量と系外から購入す る燃料量の削減が消化方式で大きく現れるためである. 余剩消化ガスを焼却炉の補助燃料として使用してもな お余る消化ガスのエネルギー価值は加算していないが 乙れを考慮すると図-15の破線の值となる.污泥中の有 機物含有率が高くなる状況においては，消化方式が生 方式に比べエネルギー消費面で非常に優れた省エネル ギーシステムといえる.

遠心濃縮の導入効果についてみると, 污泥の有機物 含有率が低く污泥の保有するエネルギー価值の小さい 領域では, 污泥濃度を強制的に高めることが総エネル
ギー削減に対する寄与率屯高く大きな効果を示す，他 方污泥の有機物含有率が高く污泥の保有するエネルギ 一価値の大きい領域では, 濃度を高めることによる寄 与率が小さくなり遠心濃縮の導入による削減効果が明 瞭に現れててない。

遠心脱水方式を例にとり，污泥中の有機物含有率の 变化が建設費, 処理原価及び総エネルギー消費量の各 因子に与える影響をみてきたが，その結果将来予想さ れる有機物含有率の増大に対し, 一般に消化方式は生 方式に比へ建設費については劣るあのの処理原価及び総 エネルギー消費量で優れており，今後益々より良好な評価 位置に移行していくことが予測できる．またての消化 方式に遠心濃縮を導入すると, 建設費処理原価と総工 ネルギー消費量が改善され, その効果は含有率の高い 域で小さく，低い域で大きい。

\section{第 5 節 最適システムの総合評価}

建設費・処理原価等の経済性にかかる因子, 並びに 臭気・総エネルギー消費量等の因子を個々に用いてシ ステムの評価を前節まで行なってきた，各々の評価因 子は異なった意義をもち, 重要性の度合は処理場の置 かれている状況により異なるため，すべての因子に重 み付けをして，定量的に評価することは困難である。 本節では, システムの最適性を総合的に評価する一手法

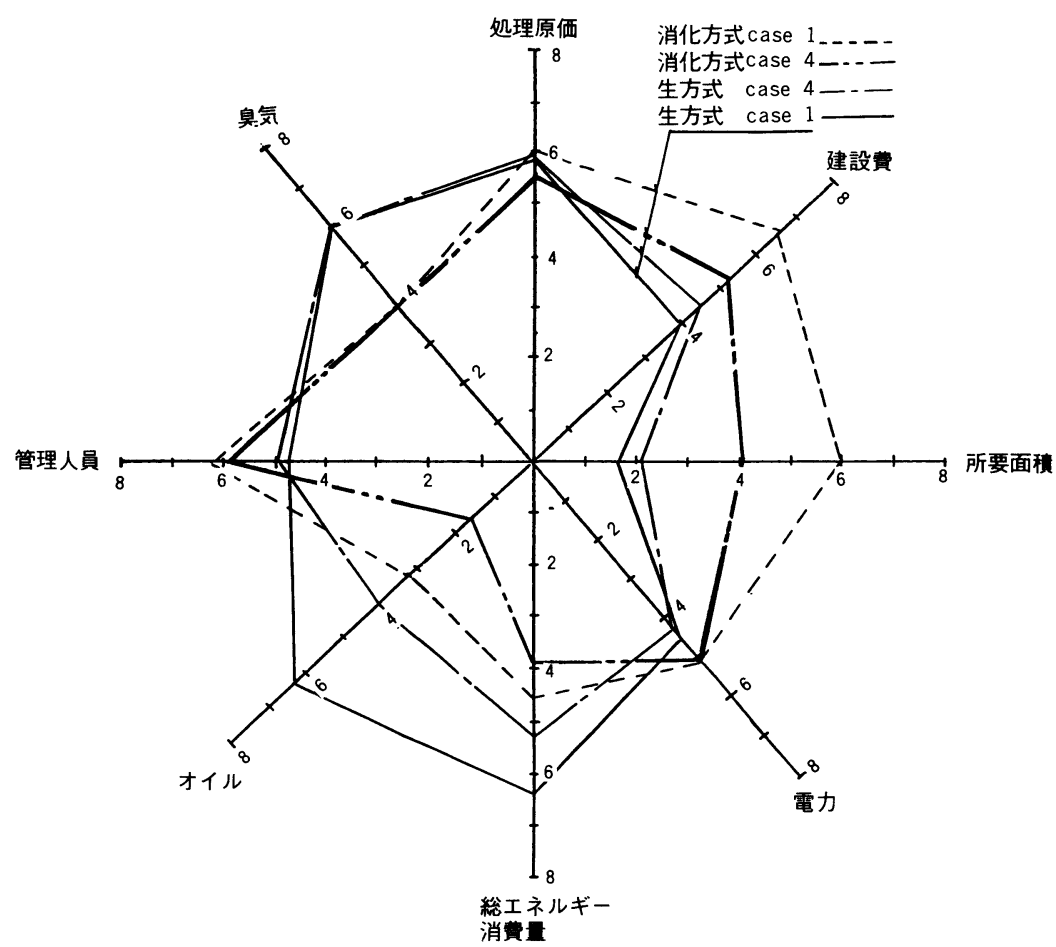

図-16 消化と生方式システムの比較(遠心脱水の場合) 
を提示し, 最適システムについての考察を行う.

本研究で試みたシステムの総合評価方法は, 評価因 子の中から 8 因子を選び, それぞれの因子を軸とし, 相対比較值で表したオクタゴングラフによるあのある. 図-16は遠心脱水方式を例として消化方式と生方式を 比較したオクタゴングラフである.

処理原価と電力においては両方式間に大きな差はな く，建設費及び所要面積という初期投資的要素の大き な因子と管理人員の因子では生方式が優れ，臭気及び エネルギーというシステムの運営上の因子では消化方 式が優れている．各評価因子の重要度が同程度である なら, 最適システムはオクダゴングラフの数值の総 和が最小のものである。しかし，システムを選択する 際には, 種々の拘束条件が存在し, 各評価因子間の相 対的重要度は社会情勢や自治体等により異なるのが一 般的である。それ故, システムの最適性を評価するた めには，各評価因子に重み付けを行い総合的に考察す

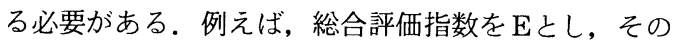
最小値を示すあのを最適とする方法がある.

$$
\begin{aligned}
\mathrm{E}= & \mathrm{c}_{1} \mathrm{x}_{1}+\mathrm{c}_{2} \mathrm{x}_{2}+\cdots \cdots \cdots+\mathrm{c}_{8} \mathrm{x}_{8} \\
& \mathrm{x}_{\mathrm{i}} \text { : 各評価因子の相対比較値 } \\
& \mathrm{c}_{\mathrm{i}} \text { ：各評価因子の重み係数 }
\end{aligned}
$$

ここで, 臭気・管理人員・エネルギーに他の因子より
大きな重みを置いて総合評価すると, 消化方式が生方 式より優れていると判断できる.

図-17及び図-18は，それぞれ生方式と消化方式にお ける濃縮法別の比較をしたオクタゴングラフである. 脱水方式は遠心脱水方式である.生方式の図-17におい ては, 重力濃縮法 (case 1)を基準にして比較すると, 消費エネルギーについては機械濃縮法(case 2,3,4)を 導入した効果がはっきり表われているが，建設費では 割高の傾向を示しており, 総合的には濃縮法による大 きな差はないと判断できる.消化方式の図-18において は，濃縮法による差を認めることができる，機械濃縮 法導入の効果は, 建設費, 所要面積, 総エネルギー消費量, オイルの因子で現われており, 中であcase 4 はすべて の因子で最も優れているので, 総合的にも, 消化方式 においては最適な濃縮方式であると判断できる.

図-19及び図-20は，消化方式を前提として，脱水方 式を比較したものである. 重力濃縮法 (case 1)の場合 が図-19であり,最も優れた濃縮方式と判断される case 4 の場合が図-20である.両図とも同様の傾向を見るこ とが出来る、遠心脱水は, 臭気, オイル及び総エネル ギー消費量の因子でやや劣るあのの, 処理原価, 建設 費, 所要面積, 管理人員, 電力の因子では優れている. ベルトプレス脱水は, 遠心脱水と比較すると管理人員

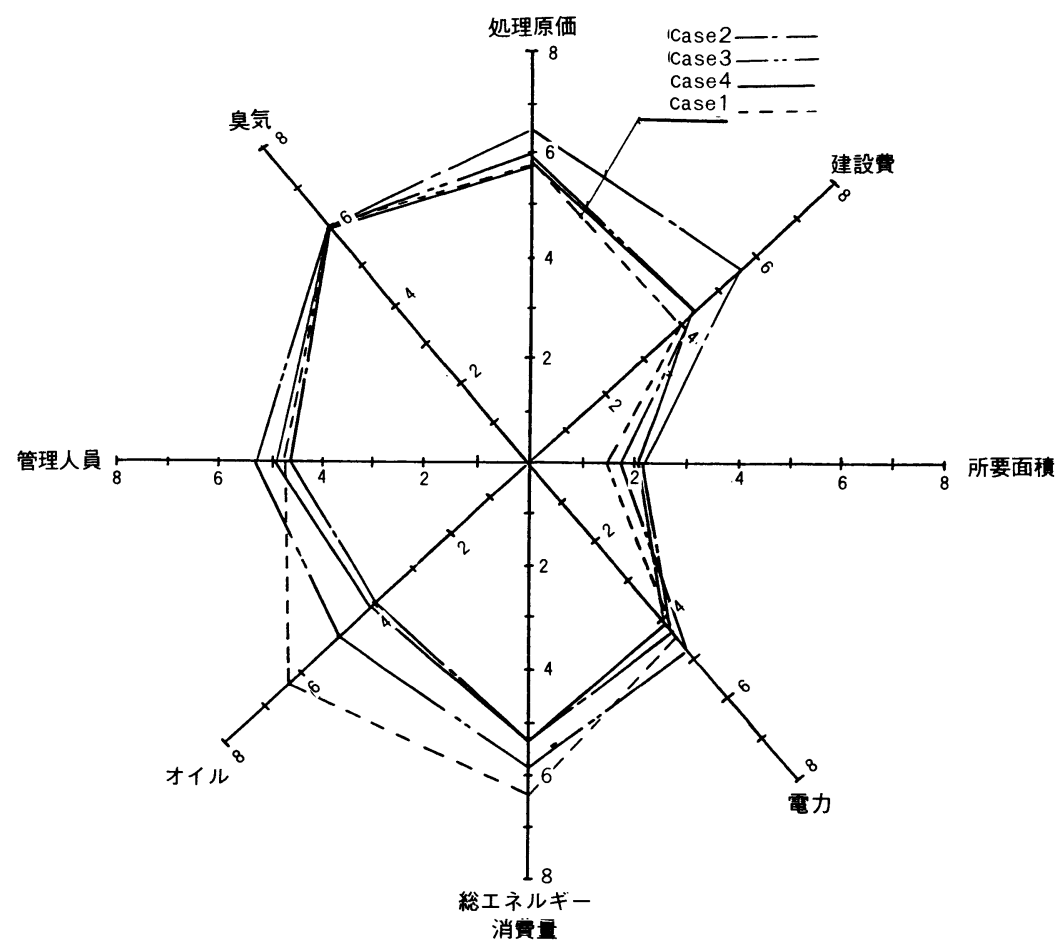

図-17 濃縮法別の生方式システムの比較（遠心脱水の場合） 


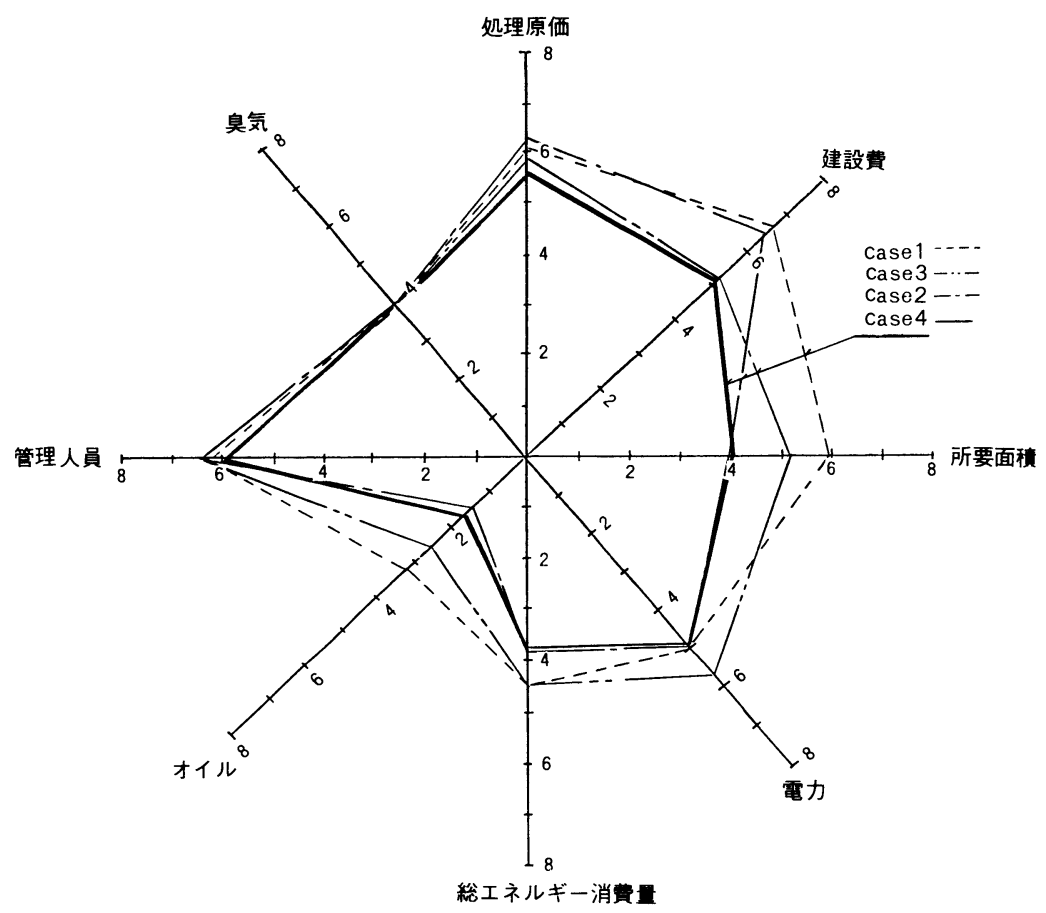

図-18 濃縮法別の消化方式システムの比較（遠心脱水の場合）

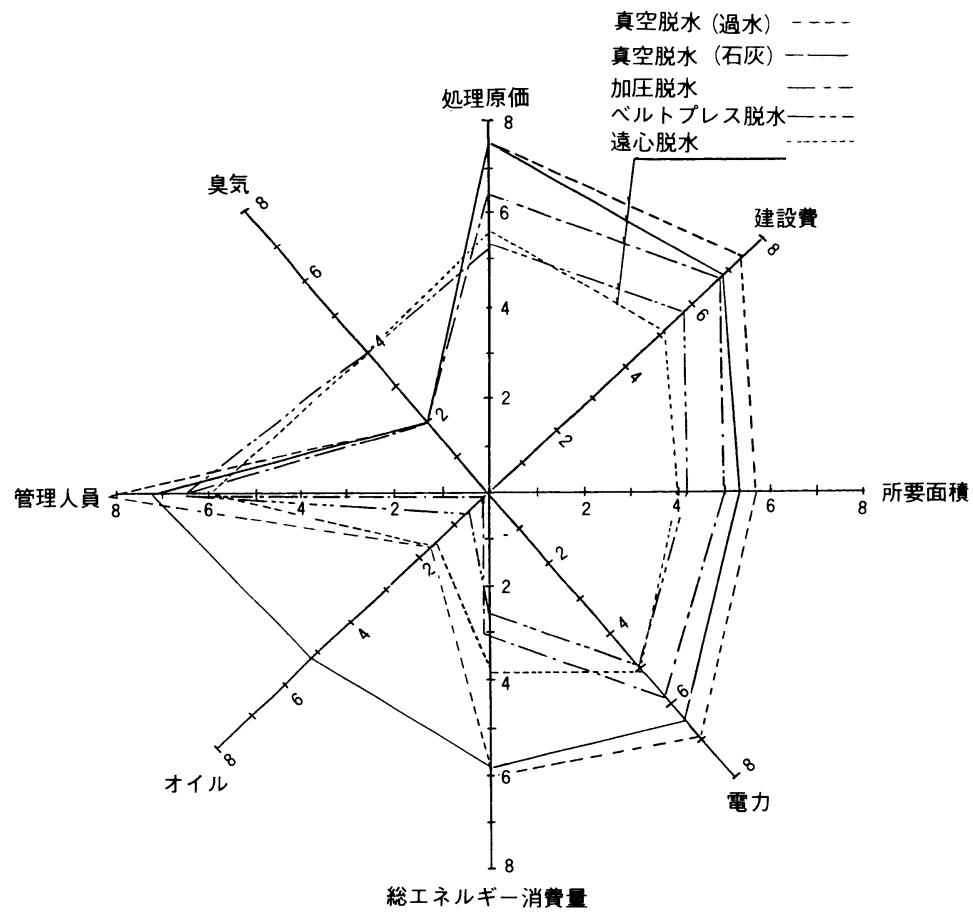

図-19 脱水法別の消化方式システムの比較(重力濃縮case 1 の場合)

で劣るあのの消費エネルギー面では優れており，他の 因子は遠心脱水之同程度である，加圧脱水は，臭気及 びオイルで優れており，真空脱水は臭気で優れている。
従って遠心又はベルトプレス脱水方式が不利となる臭 気因子に重みづけを行なったとしてあ，相対的に両方 式が優れていると判断できる。 


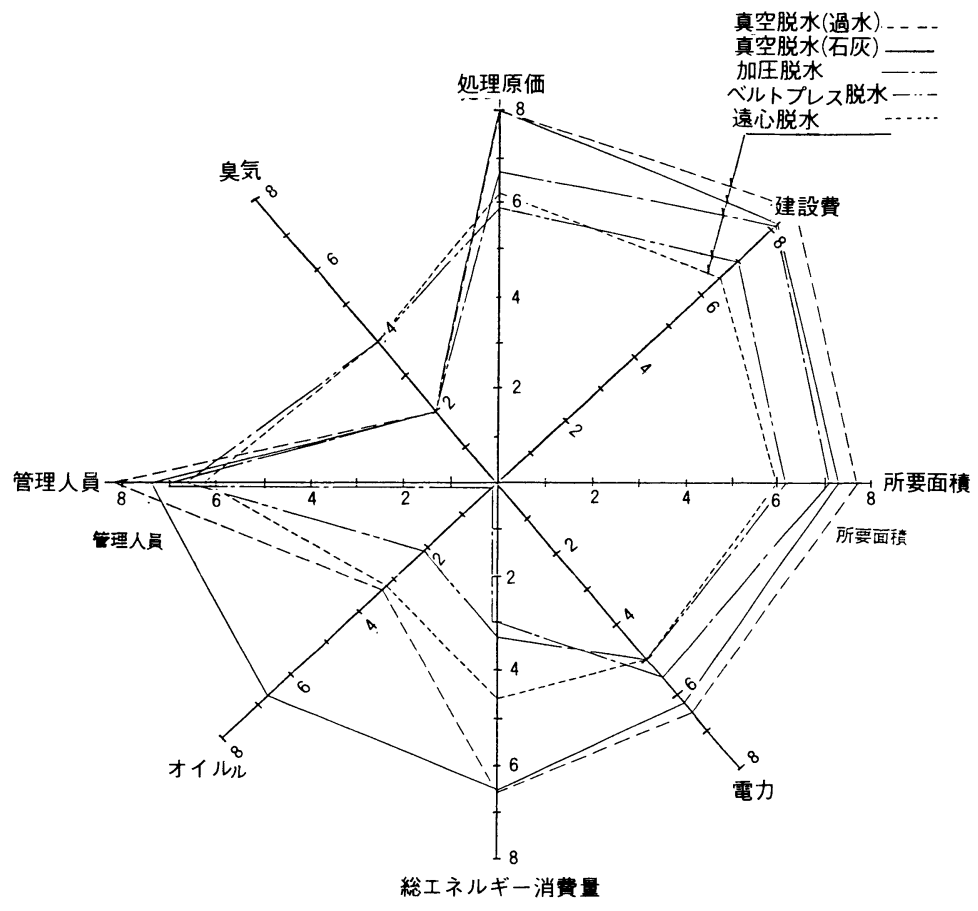

図-20 脱水法別の消化方式システムの比較 (遠心濃縮 case 4 の場合)

大阪市では総合的にシステムの最適性を評価する際, 污泥処理の経費, 住居地に隣接する処理場の立地条件, 省エネルギー及び省力化に特に配慮している，従って 評価因子の中で処理原価，臭気，総エネルギー消 費量と管理人員の 4 つの因子を重視すれば，初沈 污泥は重力濃縮, 余剰污泥は重力濃縮後遠心濃縮し, 得られた高濃度の污泥を消化，そして遠心あるいはべ ルトプレスで脱水後焼却するシステムが優れ, 又との システムは前節で述べた様に将来の污泥性状の变化を 考慮に入れても対応性が良く総合的に優れていると判 断できる。

\section{結 語}

污泥処理規模30ton DS/日のモデルを使い, 消化方 式と生方式, 濃縮法, 脱水法の組合せから40種の異っ たシステムを選び污泥処理システム評価を行った。

その評価に際し, 処理原価(起債利子＋減価償却費 十現場管理費), 各種エネルギー消費量, 管理人員, 所 要面積及び臭気等を評価因子として選んだ。こてで各 種エネルギーの消費実態を総合的に把握するためオイ ル, 電力及び薬品を消費オイル量で換算した総エネル ギー消費量という新しい評価因子屯導入した。

消化方式では，污泥中の有機物を消化プロセスで減
じることが可能なためそれ以降の脱水・焼却プロセス での施設容量を抑制でき，さらに管理運営面において あ脱水用薬品量の削減と, エネルギー価值のある污泥 中の有機物を消化ガスに転換でき購入オイルの削减が 可能であるという利点を明らかにした。また今日処理 場が周辺環境に与える臭気問題が深刻化しているが, 消化污泥は, 生污泥に比べ臭気濃度は $1 / 2$ ～ $1 / 7$ とさく 臭気対応が容易になることを指摘した，各評価因子を 考察した結果, 消化方式は生方式に比べオイル, 総エ ネルギー消費量及び臭気の評価因子で優れ，初期投資 的要素の大きな建設費と所要面積の評価因子において 劣り, 処理原価の評価因子では両方式は同等である乙 とが明らかになった。

しかし消化方式において濃縮プロセスに, 機械濃縮, なかでも case 4 の方式による遠心濃縮法の導入は,各評 価因子の改善に大きく寄与し, 又生方式と比べ劣ると される建設費や所要面積の評価因子を生方式の評価値 に大幅に近づけることが可能であることが分った，又 将来の污泥性状の変化, すなわち污泥の有機物含有率 の増大に伴う污泥濃度の低下を考えた時屯, 遠心濃縮 〜消化システムは, 污泥濃度を高く維持でき, 污泥の 減量効果が大きいと同時に, 有機物のもつエネルギー を消化ガスとして多量に有効利用できる点で, 他のシ 
ステムより優れていることを明らかにした。

脱水機種の選択においては，ケーキ含水率が焼却の 補助燃料に関係してオイルに, 薬品の種類と使用量が 臭気と総エネルギー消費量に, さらに脱水機 1 台当り の処理容量が管理人員に大きな影響を与えていること が明らかになり, 総合的に評価すると, 遠心又はベル トプレス脱水法が優れていると判断できた。

システムの評価因子は, 自治体をとりまく社会情勢 や周辺環境条件により各々の重みは異なる。本市では 総合的にシステムの最適性を評価する際, 用地につい ては, 概ね既得の敷地内で整備が可能なので, 評価 因子の中で処理原価，臭気と総エネルギー消費量の 3つの因子に重みをつけ, 同時に将来の污泥性状の 変化に対しても有利に展望できることを考慮した。そ の結果, 初沈污泥は重力濃縮, 余剩污泥は重力濃縮後 遠心濃縮し, 高濃度の污泥を消化, そして遠心あるい はベルトプレスで脱水後焼却するシステムを最も高く 評価できる。

(おわり)

\section{文献}

1 ）油谷昭夫「下水処理場で使用するエネルギーと最終污 泥量についての調查報告」大阪市下水道局下水道技術 報告集，No. 3，45 昭和56年 3 月.

2 ) 高柳枝直ほ加污泡処理処分に関する基礎調査」大阪市 下水道局下水道技術報告集，No. 4,380 昭和 57 年 3 月.

3 高柳枝直ほか「モデル計算による脱水方法の比較検討」 月刊下水道 $5(10), 58(1982)$.

4 ) 松永一成ほか「污泥処理の問題点とその対策 その 1 濃縮」水処理技術, 26 (11), 805 (1985)。

5 ) 松永一成ほか「污混処理の問題点とその対策 その 1 (続)」水処理技術，26(12)，881 (1985).

6 ) 松永一成ほか「污泥処理の問題点とその対策 その 2 嫌気性消化」水処理技術，27（1），27(1986).

7.8 ) 松永一成ほ加「污泥処理の問題点亡その対策 その 2 嫌気性消化 (II) (III)」水処理技術, 27 (2), 1986.

9 ) 日本銀行統計局「物価指数年報」(1977) (1984).

10）大阪市下水道局「昭和 59 年度下水道事業決算書」.

11）楠本光秀「下水処理場で使用する薬品等のエネルギー 原単位」大阪市下水道局下水道技術報告集, No. 3 , 33 昭和 56 年 3 月.

\section{製品ニュース}

〈クーリングタワー・冷却水槽用 $>$

\section{滅菌・防藻ガラス水処理剤・バイオシェア一SG}

クーリングタワーや冷却水槽に発生するバクテリア や藻類を除去する無害なガラス水処理剤が, 山本徳治 工学博士の指導で開発された。

このガラス水処理剂は, ホウケイ酸塩系のガラスを 主成分とし, これに一価の銀イオン $\left(\mathrm{Ag}^{+}\right)$を含む溶解 性ガラス(Solubility Glass) である.

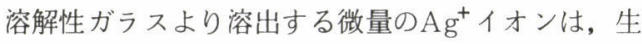
物の細胞に直接作用し, バクテリアや藻類を殺滅する 6ので, 殺菌や防藻に必要な $\mathrm{Ag}^{+}$イオンの濃度は, 処 理水の条件や, 水中微生物の数によって異なるが, 一 般には， $0.02 \sim 0.07 \mathrm{ppm}$ で充分な効果が期待できる. また，水温が低い場合よりあ高い場合や，酸性よりも アルカリ性の方が殺菌効果が大きい.

バイオシュアーSGには, 活性イオンである $\mathrm{Ag}^{+}$イオ ンが $\mathrm{Ag}^{2} \mathrm{O}$ に換算して, $0.2 \sim 1.5$ 重量 $\%$, 溶解性ガラ ス中に均質に含まれている.
一般にガラスは水に溶解し難い上思われているが, ガラスの構造は, アモルファス特有の粗な構造である ので，ガラス組成老選択するととによって一時間から 数年にわたり一定速度で溶解させることが可能であり 含まれている $\mathrm{Ag}^{+}$インは, ガラスの溶解とともに, 安定した状態で一定濃度で溶出し, 殺菌や防藻に有効 に作用する。

\section{問い合せ}

近畿パイプ技研㑣〔600 京都市下京区河原町通五 条上る]

Tel 075-343-4450

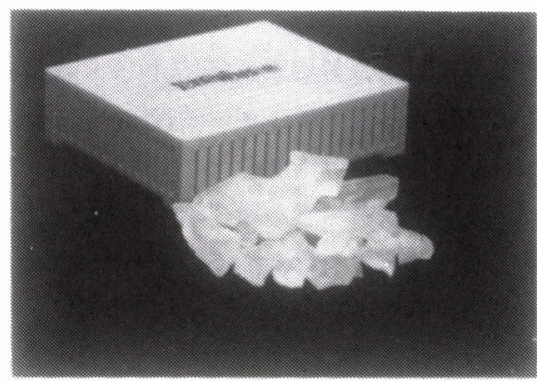

